\title{
Screening for Type 2 Diabetes Risk Factors in a Greek Municipality towards Health-literate Healthcare
}

\author{
Bakides Sofoclis", Kushitashvili Nino, Sakellariadis George
}

General Hospital of Molaoi Lakonia, Greece

Copyright $\mathrm{C} 2017$ by authors, all rights reserved. Authors agree that this article remains permanently open access under the terms of the Creative Commons Attribution License 4.0 International License

\begin{abstract}
Diabetes prevention is possible and a lot of strategies have been implemented worldwide. Unfortunately, we lack systematic efforts of combined Type 2 Diabetes risk factors screening with the concept for patients knowledge and evaluation of health information. This is true in semi-urban Greek areas stricken by the socio-economy crisis. We used the FINDRISK questionnaire and a knowledge attitude and perceptions questionnaire for cardiovascular risk factors. Totally 358 people were recruited from March to June 2014. Young doctors examined the patients and filled in the questionnaires after their fully informed consent. We have found 75 people $(20,95 \%)$ with score $>15$. Mean age: 52,14 years and mean BMI: $27,43 \mathrm{~kg} / \mathrm{m}^{2}$ Accordingly their knowledge about health risk factors $>90 \%$ knew the significance of high blood cholesterol, Diabetes, bad diet, exercise, smoking, obesity and hypertension, but over $60 \%$ underestimated their exact mortality impact on cardiovascular events. In our area pilot study, the burden of the problem for future development of T2D is probably heavy. Although health risk factors knowledge is growing, there are gaps in the field of person oriented methodology approach for enhanced health literacy. We need the development of targeted intervention programmes towards interdisciplinary working, transparent decision-making and active health-literated involvement of patients.
\end{abstract}

Keywords Screening, Diabetes Type 2, Risk Factors, Health-literate, Healthcares

\section{Introduction}

The International Diabetes Federation's global estimates for 2011 suggest that 52 million Europeans aged 20-79 years old have DM and by 2030 this number will increase to over 64 million. [1]

In 2011, 63 million Europeans had IGT (Impaired Glucose Tolerance). A total of 317 million women and 281 million men worldwide died with DM (Diabetes Mellitus) in 2011, most from CVD (Cardiovascular Disease). The European healthcare expenditure in 2011 for DM was about 75 billion Euros and by 2030 is projected to increase to 90 billion. There is a lack of a unique biological marker when diagnosing T2DM (Type 2 Diabetes Mellitus) - besides post-prandial plasma glucose (PG) - that would separate IFG (Impaired Fasting Glucose), IGT, or T2DM from normal glucose metabolism.

T2DM develops following a prolonged period of euglycemic Insulin Resistance, which progresses to DM with increased risk of vascular complications. The present definition of DM is based on the level of glucose at which retinopathy occurs, but macrovascular complications such as cerebrovascular, coronary and peripheral artery disease appear earlier and are often present at the time when T2DM is diagnosed. Over $60 \%$ of people with T2DM develop CVD, a severe and costly complication. Thus, CVD risk should be given a higher priority when cut-points for hyperglycaemia are defined and should be re-evaluated frequently based on the CVD risk.

The DECODE study reported data on disorders of glucose metabolism in European populations. [16]

The data on $\mathrm{HbAlc}$ in these populations indicate major discrepancies, compared with results from an OGTT (Oral Glucose Tolerance Test), although this was not confirmed in DETECT-2. [17, 18]

In Europeans, the prevalence of DM rises with age in both genders. Thus, $10 \%$ of people below 60 years, $10-20 \%$ between 60 and 69 years and 15-20\% above 70 years have been found with previously known DM and in addition similar proportions have detected asymptomatic DM. This means that the lifetime risk for DM is $30-40 \%$ in European populations. Also, the prevalence of IGT increases linearly from about $15 \%$ in middle aged to $35-40 \%$ in elderly Europeans. This is true even for HbAlc increases with age in both genders. [16,19]

In the US the prevalence of type 2 diabetes is increasing too, with age from $4,5 \%$ in 1995 to $8,2 \%$ in 2010 .It is estimated from the ADA that the economic cost of Diabetes increased from 2007 to 2012 . Under this trend it is projected that around 2050, 1 in every 3 adults will have Diabetes (diagnosed or not) $[1,2]$

Today, partnerships with patients are at the forefront of healthcare service delivery and quality improvement efforts worldwide [40]. Nevertheless, we luck, so far, the 
development of a systematic strategy from the HPH (Health Promoting Hospitals and Health Services) Network to involve patients in health promoting healthcare.

Furthermore, recommendations and accordance to definitions by WHO, partnering with patients, families and citizens in HPH Network requires that their needs and capabilities define direct service provision [38].

Patient-centredness is also a priority in Type 2 Diabetes (T2D) care. Identifying subgroups at high risk of poor outcomes is an important goal. In addition to obesity, age is one of the most important risk factors for T2D and the burden of the disease is very high in older age groups. So a key approach is to increase health promotion efforts especially for remote areas' T2D patients with difficult socioeconomic living conditions.

Diabetes prevention is possible and we know a lot of prevention strategies which have been implemented worldwide. Unfortunately, we lack systematic efforts of combined Type 2 Diabetes risk factors screening with the emerging concept for patients knowledge, ability to interpret and evaluate health information. Only then we can support more effective salutogenic life processes. This is even truer in semiurban Greek areas like our Municipality with much population groups stricken by the ongoing socio-economy crisis.

The aim of this pilot study was, for the first time in our area, to identify high-risk subjects for T2D combined with their evaluation on health risk factors using the FINDRISK questionnaire and a knowledge attitude and perceptions questionnaire for cardiovascular risk factors both validated in Greece.

\section{Materials and Methods}

More than 10 diabetes risk assessment tools have been developed world-wide, [8-19].

Components of seven diabetes risk models or scores with potential for adaptation for use in routine clinical practice are depicted at the following table:

Table 1. Diabetes Risk Models Scores

\begin{tabular}{|c|c|c|c|}
\hline $\begin{array}{l}\text { Score/study name, country, } \\
\text { reference }\end{array}$ & Risk factors included in score & EXTERNAL & VALIDATION \\
\hline $\begin{array}{l}\text { ARIC(Atherosclerosis Risk } \\
\text { in Communities), Germany, } \\
\text { Schmidt } 2005\end{array}$ & $\begin{array}{c}\text { Age, ethnicity, waist circumference, } \\
\text { height, systolic blood pressure, } \\
\text { family history of diabetes, } \\
\text { Fasting plasma glucose levels, triglyceride levels, } \\
\text { HDL, cholesterol levels }\end{array}$ & $\begin{array}{c}2010, \text { USA } \\
\text { AUROC }=0.84\end{array}$ & $\begin{array}{l}\text { Hosmer-Lemeshow } \\
\quad \mathrm{P}<0.001 \text {, after } \\
\text { recalibration } \mathrm{P}>0.10\end{array}$ \\
\hline $\begin{array}{c}\text { Ausdrisk, } \\
\text { Australia, Chen } 2010\end{array}$ & $\begin{array}{l}\text { Age, sex, ethnicity, parental history of diabetes, } \\
\text { history of high blood glucose, use of } \\
\text { antihypertensive drugs, smoking, physical activity, } \\
\text { waist } \\
\text { circumference }\end{array}$ & $\begin{array}{l}\text { Not externally validated but has } \\
\text { been studied as part of an } \\
\text { intervention to improve } \\
\text { outcomes } \\
\text { Hosmer-Lemeshow } \mathrm{P}=0.85\end{array}$ & \\
\hline $\begin{array}{l}\text { Cambridge risk score, } \\
\text { UK,Rahman2008 }\end{array}$ & $\begin{array}{l}\text { Age, sex, use of current corticosteroids, use of } \\
\text { antihypertensive drugs, family history of diabetes, } \\
\text { body mass index, smoking }\end{array}$ & $\begin{array}{c}2010, \mathrm{UK} \\
\text { AUROC }=0.72\end{array}$ & $\begin{array}{l}\text { Hosmer-Lemeshow } \\
\qquad \mathrm{P}=0.77\end{array}$ \\
\hline $\begin{array}{c}\text { FINDRISC, } \\
\text { Finland, Lindstrom } 2003\end{array}$ & $\begin{array}{l}\text { Age, body mass index, waist circumference, use of } \\
\text { antihypertensive drugs, history of high blood } \\
\text { glucose, physical in activity, daily consumption of } \\
\text { vegetables, fruits, and berries }\end{array}$ & $\begin{array}{l}\text { 2010, Holland, Denmark, } \\
\text { Sweden, UK, Australia } \\
\text { AUROC }=0.76\end{array}$ & $\begin{array}{c}\text { Hosmer-Lemeshow } \\
\qquad \mathrm{P}=0.27\end{array}$ \\
\hline $\begin{array}{l}\text { Framingham Offspring } \\
\text { Study, USA, } \\
\text { Wilson } 2007\end{array}$ & $\begin{array}{c}\text { Fasting plasma glucose levels, body mass index, } \\
\text { high density lipoprotein cholesterol levels, parental } \\
\text { history of diabetes, triglyceride levels, blood } \\
\text { pressure }\end{array}$ & $\begin{array}{c}\text { USA } 2010 \\
\text { AUROC }=0.78\end{array}$ & $\begin{array}{l}\text { Hosmer-Lemeshow } \\
\mathrm{P}<0.001 \text {, } \\
\text { after recalibration } \\
\mathrm{P}>0.10\end{array}$ \\
\hline $\begin{array}{l}\text { San Antonio } \\
\text { Risk score, clinical model, } \\
\text { USA, Stern } 2002\end{array}$ & $\begin{array}{c}\text { Age, sex, ethnicity, } \\
\text { Fasting } \\
\text { Plasma } \\
\text { glucose levels, systolic } \\
\text { Blood pressure, } \\
\text { high density } \\
\text { Lipoprotein } \\
\text { Cholesterol } \\
\text { levels, body mass index, } \\
\text { Family } \\
\text { History of diabetes in first degree relative }\end{array}$ & $\begin{array}{c}\text { 2010, USA } \\
\text { 2010,Iran 2010,UK } \\
\text { 2010, Iran } \\
\text { AUROC } \\
0.83 \\
0.83 \\
0.78 \\
0.78\end{array}$ & $\begin{array}{c}\text { Hosmer-Lemeshow } \\
\mathrm{P}<0.001 \text {, } \\
\text { after recalibration } \\
\mathrm{P}>0.10 \\
\text { Hosmer-Lemeshow } \\
\mathrm{P} \leq 0.001 \\
\text {,after recalibration } \\
\mathrm{P}=0.131 \\
\text { Hosmer-Lemeshow } \\
\mathrm{P}=0.42 \text {; } \\
\text { Hosmer-Lemeshow } \\
\mathrm{P}=0.264\end{array}$ \\
\hline $\begin{array}{l}\text { QDScore, UK, } \\
\text { Hippisley-Cox } \\
2009\end{array}$ & $\begin{array}{l}\text { Age, sex, ethnicity, body mass index, smoking, } \\
\text { family, History Of diabetes, Townsend } \\
\text { Deprivation } \\
\text { score, treated hypertension, cardiovascular disease, } \\
\text { current use of corticosteroids }\end{array}$ & $\begin{array}{c}2011 \text { UK } \\
\text { AUROC }=0.80 \text { MEN } \\
\text { AUROC }=081 \\
\text { WOMEN }\end{array}$ & $\begin{array}{l}\text { Brier score: } \\
0.053 \text { men, } 0.041 \\
\text { women }\end{array}$ \\
\hline
\end{tabular}


Among them, Finnish Diabetes Risk Score (FINDRISC) is one of the most commonly used risk score in detecting undiagnosed diabetes. FINDRISC has some advantages over other diabetes risk scores.

First, FINDRISC is a simple self-administered questionnaire which can be used as a diabetes screening in primary care or community settings. It can be understood and easily calculated by a person or clinical personnel without the need of any laboratory test.

Second, FINDRISC was developed initially in a prospective study with an excellent performance in predicting the 10-year diabetes risk in Finnish population [12].

Third, FINDRISC includes eight clearly defined questions that cover all well proven risk factors of diabetes.

Fourth, FINDRISC has been evaluated in detecting individuals with undiagnosed diabetes and prediabetes in a cross-sectional study not only in Finland [21] but also in 15 other countries or regions and gained good validity in most of these populations [20], [22-35].

However, most previous studies have been conducted in European countries with the majority of participants as Caucasians [22-28] or other single racial groups [20], [29-35].

We have used the FINDRISK questionnaire because it was the only available validated from 2010 and there was no other available because of the Greek socio-economy crisis.

We used a knowledge attitude and perception questionnaire for cardiovascular risks factors which is validated in Greece.

Every study participant was asked about their knowledge for health risk factors like high blood cholesterol, Diabetes, bad diet habits, smoking, exercise, obesity and hypertension. They were also asked if they also knew their mortality impact according cardiovascular events.

We have also examined if there was any impact of age, BMI, marital status, number of kids, educational years, profession, employment, on the variables $<<$ attitude/perceptions about prevention $>>$ and $<<$ level of risk factors knowledge $>>$

\section{Research Design}

The study was a cross sectional one performed in the Municipality area of Monemvasia, Lakonia, Greece. The population of this Municipality, according to the 2011 last census, was 22958 persons and the great majority (95\%) was Greeks, residents of this area.

This quantitative research differs significantly from the methodological tools of knowledge acquisition, but also the theoretical starting point, with other surveys as its elements are primary. The Personal Method is also preferred, since the researcher himself comes in contact with the respondent, gives him the questionnaire and either completes it alone or the researcher writes his answers.

This pilot study was performed among 358 people attended outpatient clinics in seven areas of our Municipality, from March to June 2014. They were selected via systematic random sampling based on age and place of residence, according to the population of the seven areas of our Municipality. Informed consent was signed prior to enrollment into the study, under the instructions posed by the Ethical and Scientific Committee of our Hospital. All of them were given a set of the two questionnaires to be completed within 20 minutes during an interview and under the guidance of a Specialist Doctor (Internist or Family Doctor).

In our study, Body Mass Index (BMI) and Waist Circumference (WC) were identified from the anthropometric data measured by trained personnel. Weight and height were measured with light clothing and no shoes with the use of calibrated scales and wall-mounted stadiometers with the participants standing erect. Waist Circumference was measured in the midway of the lower rib and iliac crest using a tape.

Daily physical activity time was calculated as the sum of the minutes spent on physical activity for recreation, commuting and work for each day. The frequency of vegetables, fruits consumption was initially collected through 24-hour food recall, and only those who consumed vegetables or fruits at least 100 grams/day were considered as consuming them every day. The answers to all the questions of the FINDRISC were identified via self-reported answers given to trained junior doctors of our research team.

A score $>15$ categorizes a person at high risk for DM development for the next decade.

\section{Results}

We have found 75 persons $(20,95 \%)$ with score $>15$. Mean age: 52,14 years and mean BMI: $27,43 \mathrm{~kg} / \mathrm{m}$. Our results are depicted on the following table:

Table 2. Distribution of Test Risk Scoring in Correlation with the Gender:

\begin{tabular}{|c|c|c|c|c|c|}
\hline SCORE & $<7$ & $7-11$ & $12-14$ & $15-20$ & $>20$ \\
\hline MEN & 42 & 61 & 21 & 16 & 5 \\
N=145 & $(28.96 \%)$ & $(42.08 \%)$ & $(14.48 \%)$ & $(11.03 \%)$ & $(3.45 \%)$ \\
\hline WOMEN & 48 & 68 & 43 & 42 & 12 \\
N=213 & $(22.54 \%)$ & $(31.92 \%)$ & $(20.19 \%)$ & $(19.72 \%)$ & $(5.63 \%)$ \\
\hline TOTAL & 90 & 129 & 64 & 58 & 17 \\
N=358 & $(25.14 \%)$ & $(36.03 \%)$ & $(17.88 \%)$ & $(16.20 \%)$ & $(4.75 \%)$ \\
\hline
\end{tabular}


Unfortunately, regarding the knowledge attitude and perception questionnaire for cardiovascular risks factors, we had missing data for a variety of reasons as 95 questionnaires were excluded from the study (omission of signing the Informed consent form prior to enrollment into the study, some of the questionnaires were filled in after a second visit of the same person, some of the questionnaires were not filled in with the presence and guidance of a specialist medical doctor).

Accordingly, the knowledge of the persons included in the study about health risk factors: $>90 \%$ knew the significance of high blood cholesterol, Diabetes, bad diet, exercise, smoking, obesity and hypertension, but over $60 \%$ underestimated their exact mortality impact on cardiovascular events.

The average knowledge about cardiovascular risk factors was very good in general. (These are depicted on the following tables 3 and 4).

Positive correlation was found between educational years, profession, employment and the degree of risk factor knowledge with clear under evaluation of the true burden of smoking, lack of exercise and obesity from the lower socio-economy level participants. Positive correlation was also found between age, marital status, number of kids, educational years, profession, employment and their attitude/ perceptions about Prevention. All the above are shown on the following tables of ANOVA statistical analyses for the above mentioned variables. (tables 5-12)

Table 3. General Knowledge of Health Risk Factors Impact on Cardiovascular Events

\begin{tabular}{|c|c|c|c|c|c|}
\hline & NO & SMALL & MODERATE & BIG & VERY BIG \\
\hline HIGH BLOOD LDL CHOLESTEROL & $4.5 \%$ & $2.3 \%$ & $3.0 \%$ & $73.6 \%$ & $15.8 \%$ \\
\hline LOW BLOOD HDL COLESTEROL & $61.5 \%$ & $3.8 \%$ & $8.3 \%$ & $17.7 \%$ & $8 \%$ \\
\hline HIGH BLOOD SUGAR & $3.4 \%$ & $1.5 \%$ & $3.4 \%$ & $72.8 \%$ & $18.1 \%$ \\
\hline HIGH BLOOD PRESSURE & $2.3 \%$ & $1.1 \%$ & $1.9 \%$ & $72.1 \%$ & $21.5 \%$ \\
\hline
\end{tabular}

We have found that the general knowledge of health risk factors impact on cardiovascular events, except of that of low blood HDL value, was excellent (>90\%).

Table 4. Specific Knowledge of Cardiovascular Health Risk Factors Impact Importance

\begin{tabular}{|c|c|c|c|c|c|}
\hline & NO & SMALL & MODERATE & BIG & VERY BIG \\
\hline ARTERIAL HYPERTENSION & $0.0 \%$ & $0.0 \%$ & $2.3 \%$ & $81.9 \%$ & $15.8 \%$ \\
\hline DIABETES MELITUS & $0.4 \%$ & $0.0 \%$ & $3.0 \%$ & $76.6 \%$ & $19.6 \%$ \\
\hline DYSLIPIDEMIA & $0.0 \%$ & $1.9 \%$ & $7.2 \%$ & $78.5 \%$ & $12.1 \%$ \\
\hline BAD DIET & $0.0 \%$ & $2.3 \%$ & $9.8 \%$ & $76.2 \%$ & $11.3 \%$ \\
\hline SMOKING & $0.4 \%$ & $0.0 \%$ & $3.0 \%$ & $71.3 \%$ & $25.3 \%$ \\
\hline OBESITY & $0.4 \%$ & $0.4 \%$ & $3.4 \%$ & $74.3 \%$ & $21.5 \%$ \\
\hline ANXIETY & $0.4 \%$ & $0.0 \%$ & $5.7 \%$ & $55.5 \%$ & $38.5 \%$ \\
\hline LACK OF REGULAR EXERCISE & $0.4 \%$ & $4.5 \%$ & $12.1 \%$ & $77.0 \%$ & $5.7 \%$ \\
\hline
\end{tabular}

We have found that the specific knowledge of cardiovascular health risk factors was very satisfactory ( $88 \%$ and over ) for the studied factors

Table 5. Impact of Age and BMI

\begin{tabular}{|c|c|c|c|c|c|}
\hline & & AGE & BMI & $\begin{array}{c}\text { ATTITUDE/ } \\
\text { PERCEPTIONS ON } \\
\text { PREVENTION } \\
\end{array}$ & $\begin{array}{c}\text { LEVEL OF RISK } \\
\text { FACTORS } \\
\text { KNOWLEDGE }\end{array}$ \\
\hline \multirow{3}{*}{ AGE } & Pearson Correlation & 1 & .041 & $-.371^{* *}$ & -.067 \\
\hline & Sig. (2-tailed) & & .507 & .000 & .276 \\
\hline & $\mathrm{N}$ & 265 & 265 & 265 & 265 \\
\hline \multirow[b]{3}{*}{ BMI } & Pearson Correlation & .041 & 1 & -.074 & .011 \\
\hline & Sig. (2-tailed) & .507 & & .228 & .862 \\
\hline & $\mathrm{N}$ & 265 & 265 & 265 & 265 \\
\hline \multirow{3}{*}{$\begin{array}{c}\text { ATTITUDE/ } \\
\text { PERCEPTIONS ON } \\
\text { PREVENTION }\end{array}$} & Pearson Correlation & $-.371^{* *}$ & -.074 & 1 & .007 \\
\hline & Sig. (2-tailed) & .000 & .228 & & .905 \\
\hline & $\mathrm{N}$ & 265 & 265 & 265 & 265 \\
\hline \multirow{5}{*}{$\begin{array}{c}\text { LEVEL OF RISK } \\
\text { FACTORS KNOWLEDGE }\end{array}$} & Pearson Correlation & -.067 & .011 & .007 & 1 \\
\hline & Sig. (2-tailed) & .276 & .862 & .905 & \\
\hline & $\mathrm{N}$ & 265 & 265 & 265 & 265 \\
\hline & Sig. (2-tailed) & .478 & .407 & .012 & .000 \\
\hline & $\mathrm{N}$ & 264 & 264 & 264 & 264 \\
\hline
\end{tabular}


Our findings suggest the impact of age on the variable $<<$ Attitude /perceptions on prevention $>>(\mathrm{r}=-0.371, \mathrm{p}<0.001)$, but not any impact of BMI on the variables under evaluation.

Table 6. Impact of Marital Status

\begin{tabular}{|c|c|c|c|c|c|c|c|}
\hline \multicolumn{8}{|c|}{ ANOVA Table } \\
\hline & & & Sum of Squares & df & Mean Square & $\mathrm{F}$ & Sig. \\
\hline \multirow{3}{*}{$\begin{array}{c}\text { ATTITUDE/ } \\
\text { PERCEPTIONS ON } \\
\text { PREVENTION }\end{array}$} & Between Groups & (Combined) & 6.421 & 4 & 1.605 & 2.009 & .094 \\
\hline & \multicolumn{2}{|c|}{ Within Groups } & 207.714 & 260 & .799 & & \\
\hline & \multicolumn{2}{|c|}{ Total } & 214.136 & 264 & & & \\
\hline \multirow{5}{*}{$\begin{array}{l}\text { LEVEL OF RISK } \\
\text { FACTORS } \\
\text { KNOWLEDGE }\end{array}$} & Between Groups & (Combined) & .236 & 4 & .059 & .537 & .709 \\
\hline & \multicolumn{2}{|c|}{ Within Groups } & 28.515 & 260 & .110 & & \\
\hline & \multicolumn{2}{|c|}{ Total } & 28.750 & 264 & & & \\
\hline & \multicolumn{2}{|c|}{ Within Groups } & 126.014 & 259 & .487 & & \\
\hline & \multicolumn{2}{|c|}{ Total } & 126.818 & 263 & & & \\
\hline
\end{tabular}

The high value of $\mathrm{F}$ combined with the value of $\mathrm{p}=0.094$ show a strong statistical tendency, regarding the impact of marital status on the variable $<<$ Attitude/Perceptions on prevention $>>$. (A larger sample would surely give a clearer statistical result).

Table 7. Impact of Number of Kids

\begin{tabular}{|c|c|c|c|c|c|c|c|}
\hline \multicolumn{8}{|c|}{ ANOVA Table } \\
\hline & & & Sum of Squares & $\mathrm{df}$ & Mean Square & $\mathrm{F}$ & Sig. \\
\hline \multirow{3}{*}{$\begin{array}{c}\text { ATTITUDE/ } \\
\text { PERCEPTIONS ON } \\
\text { PREVENTION }\end{array}$} & Between Groups & (Combined) & 9.566 & 6 & 1.594 & 2.011 & .065 \\
\hline & \multicolumn{2}{|c|}{ Within Groups } & 204.569 & 258 & .793 & & \\
\hline & \multicolumn{2}{|c|}{ Total } & 214.136 & 264 & & & \\
\hline \multirow{5}{*}{$\begin{array}{l}\text { LEVEL OF RISK } \\
\text { FACTORS } \\
\text { KNOWLEDGE }\end{array}$} & Between Groups & (Combined) & 1.036 & 6 & .173 & 1.607 & .145 \\
\hline & \multicolumn{2}{|c|}{ Within Groups } & 27.715 & 258 & .107 & & \\
\hline & \multicolumn{2}{|c|}{ Total } & 28.750 & 264 & & & \\
\hline & \multicolumn{2}{|c|}{ Within Groups } & 122.873 & 257 & .478 & & \\
\hline & \multicolumn{2}{|c|}{ Total } & 126.818 & 263 & & & \\
\hline
\end{tabular}

The high value of $\mathrm{F}=2.011$ combined with the value of $\mathrm{p}=0.065$ show a strong statistical tendency, regarding the impact of the number of kids on $<<$ Attitude/Perceptions on prevention $>>$.

Table 8. Impact of Education

\begin{tabular}{|c|c|c|}
\hline EDUCATION & $\begin{array}{c}\text { ATTITUDE } \\
\text { /PERCEPTIONS ON } \\
\text { PREVENTION }\end{array}$ & $\begin{array}{c}\text { LEVEL OF RISK } \\
\text { FACTORS } \\
\text { KNOWLEDGE }\end{array}$ \\
\hline NO FORMAL SCHOOLING & 3.6667 & 4.0903 \\
\hline PRIMARY SCHOOL (GRADE $: 1-6)$ & 3.4074 & 4.0804 \\
\hline SECONDARY SCHOOL (GRADE :7-9) & 3.5095 & 4.0292 \\
\hline SECONDARY SCHOOL (GRADE $: 10-12)$ & 3.6331 & 4.0540 \\
\hline HIGHER SECONDARY & 3.5952 & 4.1736 \\
\hline BACHELOR DEGREE & 3.8354 & 4.1576 \\
\hline MSC,PHD HOLDER & 4.1964 & 4.5000 \\
\hline Total & 3.5849 & 4.1033 \\
\hline
\end{tabular}




\begin{tabular}{|c|c|c|c|c|c|c|c|}
\hline \multicolumn{8}{|c|}{ ANOVA Table } \\
\hline \multicolumn{3}{|c|}{ IMPACT OF EDUCATION } & Sum of Squares & df & Mean Square & $\mathrm{F}$ & Sig. \\
\hline \multirow{3}{*}{$\begin{array}{c}\text { ATTITUDE/ } \\
\text { PERCEPTIONS ON } \\
\text { PREVENTION }\end{array}$} & Between Groups & (Combined) & 9.457 & 6 & 1.576 & 1.987 & .068 \\
\hline & \multicolumn{2}{|c|}{ Within Groups } & 204.678 & 258 & .793 & & \\
\hline & \multicolumn{2}{|c|}{ Total } & 214.136 & 264 & & & \\
\hline \multirow{5}{*}{$\begin{array}{l}\text { LEVEL OF RISK } \\
\text { FACTORS } \\
\text { KNOWLEDGE }\end{array}$} & Between Groups & (Combined) & 1.811 & 6 & .302 & 2.891 & .010 \\
\hline & \multicolumn{2}{|c|}{ Within Groups } & 26.939 & 258 & .104 & & \\
\hline & \multicolumn{2}{|c|}{ Total } & 28.750 & 264 & & & \\
\hline & \multicolumn{2}{|c|}{ Within Groups } & 123.751 & 257 & .482 & & \\
\hline & \multicolumn{2}{|c|}{ Total } & 126.818 & 263 & & & \\
\hline
\end{tabular}

There is an impact of education as a statistical tendency on the variable $<<$ Attitude/perceptions on prevention $>>$ and a clear impact on the variable $<<$ Level of risk factors knowledge $>>$. $(\mathrm{F}=2.891, \mathrm{p}=0.010)$.

Table 9. Impact of Major Occupation

\begin{tabular}{|c|c|c|}
\hline MAJOR OCCUPATION & $\begin{array}{c}\text { ATTITUDE/PERCEPTIONS ON } \\
\text { PREVENTION }\end{array}$ & $\begin{array}{c}\text { LEVEL OF RISK FACTORS } \\
\text { KNOWLEDGE }\end{array}$ \\
\hline SERVICE & 3.9265 & 4.1602 \\
\hline UNEMPLOYED & 4.0357 & 3.8125 \\
\hline HOUSEWIFE/UNABLE TO WORK & 3.4662 & 4.0526 \\
\hline RETIRED & 3.3143 & 4.0802 \\
\hline Total & 3.5849 & 4.1033 \\
\hline
\end{tabular}

\begin{tabular}{|c|c|c|c|c|c|c|c|}
\hline \multicolumn{8}{|c|}{ ANOVA Table } \\
\hline & & & Sum of Squares & df & Mean Square & $\mathrm{F}$ & Sig. \\
\hline \multirow{3}{*}{\begin{tabular}{|} 
ATTITUDE/PERCEPTI \\
ONS ON \\
PREVENTION
\end{tabular}} & Between Groups & (Combined) & 22.155 & 3 & 7.385 & 10.040 & .000 \\
\hline & \multicolumn{2}{|c|}{ Within Groups } & 191.981 & 261 & .736 & & \\
\hline & \multicolumn{2}{|c|}{ Total } & 214.136 & 264 & & & \\
\hline \multirow{5}{*}{$\begin{array}{l}\text { LEVEL OF RISK } \\
\text { FACTORS } \\
\text { KNOWLEDGE }\end{array}$} & Between Groups & (Combined) & .833 & 3 & .278 & 2.597 & .053 \\
\hline & \multicolumn{2}{|c|}{ Within Groups } & 27.917 & 261 & .107 & & \\
\hline & \multicolumn{2}{|c|}{ Total } & 28.750 & 264 & & & \\
\hline & \multicolumn{2}{|c|}{ Within Groups } & 125.411 & 260 & .482 & & \\
\hline & \multicolumn{2}{|c|}{ Total } & 126.818 & 263 & & & \\
\hline
\end{tabular}

The impact of occupation on the variable $<<$ Attitude/perceptions on prevention $>>$ is statistically clear $(\mathrm{F}=10.040$ and $\mathrm{p}<0.001)$. The impact of occupation on the variable $<<$ Level of risk factor knowledge $>>$ is very close to statistical significance $(\mathrm{F}=2.597$ and $\mathrm{p}=0.053)$ which is certain with a larger sample size.

Table 10. Impact of Profession

\begin{tabular}{|c|c|c|}
\hline PROFESSION & $\begin{array}{c}\text { ATTITUDE/PERCEPTIONS ON } \\
\text { PREVENTION }\end{array}$ & $\begin{array}{c}\text { LEVEL OF RISK FACTORS } \\
\text { KNOWLEDGE }\end{array}$ \\
\hline SENIOR EXECUTIVES & 3.6250 & 4.3125 \\
\hline SELF-EMPLOYED & 3.6645 & 4.1288 \\
\hline TECHNICIANS & 3.3247 & 4.0341 \\
\hline SERVICE PRIVATE & 3.9500 & 4.2375 \\
\hline SALESMEN & 3.8571 & 4.0500 \\
\hline AGRICULTURE SPECIALIZED & 3.4556 & 4.0529 \\
\hline CERTIFIED TECHNICIANS & 2.8571 & 4.5000 \\
\hline NON CERTIFIED TECHNICIANS & 4.0357 & 4.1875 \\
\hline Total & 3.5850 & 4.1115 \\
\hline
\end{tabular}




\begin{tabular}{|c|c|c|c|c|c|c|c|}
\hline \multicolumn{8}{|c|}{ ANOVA Table } \\
\hline & & & Sum of Squares & $\mathrm{df}$ & Mean Square & $\mathrm{F}$ & Sig. \\
\hline \multirow{3}{*}{$\begin{array}{l}\text { ATTITUDE/PERCEPTI } \\
\text { ONS ON PREVENTION }\end{array}$} & Between Groups & (Combined) & 11.317 & 8 & 1.415 & 1.762 & .086 \\
\hline & \multicolumn{2}{|c|}{ Within Groups } & 179.008 & 223 & .803 & & \\
\hline & \multicolumn{2}{|c|}{ Total } & 190.325 & 231 & & & \\
\hline \multirow{5}{*}{$\begin{array}{c}\text { LEVEL OF RISK } \\
\text { FACTORS } \\
\text { KNOWLEDGE }\end{array}$} & Between Groups & (Combined) & 1.818 & 8 & .227 & 2.114 & .036 \\
\hline & \multicolumn{2}{|c|}{ Within Groups } & 23.968 & 223 & 107 & & \\
\hline & \multicolumn{2}{|c|}{ Total } & 25.786 & 231 & & & \\
\hline & \multicolumn{2}{|c|}{ Within Groups } & 100.304 & 222 & .452 & & \\
\hline & \multicolumn{2}{|c|}{ Total } & 109.249 & 230 & & & \\
\hline
\end{tabular}

There is a strong statistical tendency $(\mathrm{F}==1.762, \mathrm{p}=0.086)$ for the impact of profession on the variable $<<$ Attitude/perception on prevention $>>$. Its impact on the variable $<<$ Level of risk factors knowledge $>>$ is statistically significant.

Table 11. Impact of Cigarette Smoking

\begin{tabular}{|c|c|c|}
\hline $\begin{array}{c}\text { CIGARETTE SMOKING (NUMBER OF } \\
\text { SIGARETTES) }\end{array}$ & $\begin{array}{c}\text { ATTITUDE/PERCEPTIONS ON } \\
\text { PREVENTION }\end{array}$ & \begin{tabular}{c} 
LEVEL OF RISK FACTORS KNOWLEDGE \\
\hline NONE
\end{tabular} \\
\hline$<5$ & 3.5326 & 3.1124 \\
\hline $6-10$ & 3.9048 & 4.9861 \\
\hline $10-20$ & 4.2041 & 4.0536 \\
\hline$>20$ & 3.9286 & 4.0536 \\
\hline Total & 3.5714 & 4.1033 \\
\hline
\end{tabular}

\begin{tabular}{|c|c|c|c|c|c|c|c|}
\hline \multicolumn{8}{|c|}{ ANOVA Table } \\
\hline & & & Sum of Squares & df & Mean Square & $\mathrm{F}$ & Sig. \\
\hline \multirow{3}{*}{$\begin{array}{l}\text { ATTITUDE/PERCEPTI } \\
\text { ONS ON PREVENTION }\end{array}$} & Between Groups & (Combined) & 5.883 & 4 & 1.471 & 1.836 & .122 \\
\hline & \multicolumn{2}{|c|}{ Within Groups } & 208.252 & 260 & .801 & & \\
\hline & \multicolumn{2}{|c|}{ Total } & 214.136 & 264 & & & \\
\hline \multirow{5}{*}{$\begin{array}{c}\text { LEVEL OF RISK } \\
\text { FACTORS } \\
\text { KNOWLEDGE }\end{array}$} & Between Groups & (Combined) & .184 & 4 & .046 & .420 & .794 \\
\hline & \multicolumn{2}{|c|}{ Within Groups } & 28.566 & 260 & .110 & & \\
\hline & \multicolumn{2}{|c|}{ Total } & 28.750 & 264 & & & \\
\hline & \multicolumn{2}{|c|}{ Within Groups } & 121.648 & 259 & .470 & & \\
\hline & \multicolumn{2}{|c|}{ Total } & 126.818 & 263 & & & \\
\hline
\end{tabular}

There is no impact of smoking on the variables $<<$ Attitude/perception on prevention $>>$ and $<<$ Level of risk factors knowledge $>>$

Table 12. Impact of Income

\begin{tabular}{|c|c|c|c|c|c|c|c|}
\hline \multicolumn{8}{|c|}{ ANOVA Table } \\
\hline & & & Sum of Squares & $\mathrm{df}$ & Mean Square & $\mathrm{F}$ & Sig. \\
\hline \multirow{3}{*}{$\begin{array}{l}\text { ATTITUDE/PERCEPTI } \\
\text { ONS ON PREVENTION }\end{array}$} & Between Groups & (Combined) & 9.203 & 7 & 1.315 & 1.645 & .123 \\
\hline & \multicolumn{2}{|c|}{ Within Groups } & 204.589 & 256 & .799 & & \\
\hline & \multicolumn{2}{|c|}{ Total } & 213.792 & 263 & & & \\
\hline \multirow{5}{*}{$\begin{array}{c}\text { LEVEL OF RISK } \\
\text { FACTORS } \\
\text { KNOWLEDGE }\end{array}$} & Between Groups & (Combined) & .586 & 7 & .084 & .764 & .618 \\
\hline & \multicolumn{2}{|c|}{ Within Groups } & 28.090 & 256 & .110 & & \\
\hline & \multicolumn{2}{|c|}{ Total } & 28.676 & 263 & & & \\
\hline & \multicolumn{2}{|c|}{ Within Groups } & 121.017 & 255 & .475 & & \\
\hline & \multicolumn{2}{|c|}{ Total } & 126.779 & 262 & & & \\
\hline
\end{tabular}

There was no impact of the income on the two variables we have studied. 


\section{Discussion}

Cardiovascular disease shares several risk factors with type 2 diabetes. The Finnish Diabetes Risk Score (FINDRISC) is a reasonably good predictor of CHD, stroke and total mortality. The areas under the ROC curves (AUC) were $71 \%$ for $\mathrm{CHD}, 73 \%$ for stroke, and $68 \%$ for total mortality in men and 78,68 , and $72 \%$ in women, respectively. The addition of systolic and diastolic blood pressures, total and high-density lipoprotein cholesterol, and smoking increased the AUC values modestly (the change of the absolute values from 2.6 to $6.5 \%$ ), but the additional use of plasma glucose had only a slight effect on the AUC values for CHD and stroke.[46]

Population testing of blood glucose to determine CV risk is not recommended, due to the lack of affirmative evidence that the prognosis of CVD related to T2DM can be improved by early detection and treatment. [20, 21] Screening of hyperglycaemia for CV risk purposes should therefore be targeted to high-risk individuals. The Anglo-Danish-Dutch Study of Intensive Treatment in People with Screen Detected Diabetes in Primary Care (ADDITION) study provided evidence that the risk of CVD events is low in screen-detected people with T2DM. Screening may, however, facilitate CV risk reduction and early detection may benefit progression of microvascular disease, which may make screening for T2DM beneficial. [22]

In addition, there is an interest in identifying people with IGT, since most will progress to T2DM and this progression can be retarded by lifestyle interventions. [23-27]

The diagnosis of DM has traditionally been based on the level of blood glucose that relates to a risk of developing micro- rather than macrovascular disease. The DETECT-2 study analysed results from 44000 persons in nine studies across five countries. [18]

It was concluded that a $\mathrm{HbA} 1 \mathrm{c}$ of $6.5 \%(48 \mathrm{mmol} / \mathrm{L})$ and an FPG of. $6.5 \mathrm{mmol} / \mathrm{L}(117 \mathrm{mg} / \mathrm{dL})$ together gave a better discrimination in relation to the view-adopted by the ADA and $\mathrm{WHO}$ - that, for general population, screening an $\mathrm{HbA} 1 \mathrm{c} .6 .5 \%$ is diagnostic of DM, but between $6.0-6.5 \%$, an FPG needs to be measured to establish a diagnosis. [3, 4]

Caveats exist in relation to this position, as extensively reviewed by Hare et al. Problems exist in relation to pregnancy, polycystic ovary syndrome, haemoglobinopathies and acute illness mitigating against its use under such circumstances.[28,29]

Moreover, the probability of a false negative test result, compared with the OGTT, is substantial when attempting to detect DM by measuring only FPG and/or HbAlc in an Asian population. [30]

A study in Spanish people with high risk, i.e..12/26 points in the Finnish Diabetes Risk Score (FINDRISC) study, revealed that $8.6 \%$ had undiagnosed T2DM by the OGTT, whilst only $1.4 \%$ had an HbA1c $6.5 \%$, indicating a further need to evaluate the use of $\mathrm{HbAlc}$ as the primary diagnostic test in specific populations. [6]

There remains controversy regarding the approach of using $\mathrm{HbAlc}$ for detecting undiagnosed DM in the setting of coronary heart disease and $\mathrm{CV}$ risk management, although advocates argue that $\mathrm{HbAlc}$ in the range $6.0-6.5 \%$ requires lifestyle advice and individual risk factor management alone, and that further information on $2 \mathrm{hPG}$ does not alter such management.[4-7], [28]

The approaches for early detection of T2DM and other disorders of glucose metabolism are:

(i) measuring PGorHbA1c to explicitly determine prevalent T2DM and impaired glucose regulation;

(ii) using demographic and clinical characteristics and previous laboratory tests to determine the likelihood for T2DM and

(iii) collecting questionnaire-based information that provides information on the presence of aetiological risk factors for T2DM. The last two approaches leave the current glycaemic state ambiguous and glycaemia testing is necessary in all three approaches, to accurately define whether T2DM and other disorders of glucose metabolism exist.

However, the results from such a simple first-level screening can markedly reduce the numbers who need to be referred for further testing of glycaemia and other CVD risk factors. Option two is particularly suited to those with pre-existing CVD and women with previous gestational DM, while the third option is better suited to the general population and also for overweight/obese people.

Several DM risk scores for DM have been developed. Most perform well and it does not matter which one is used, as underlined by a recent systematic review. The Finnish Diabetes Risk Score is the most commonly used to screen for DM risk in Europe. [31]

This tool, available in almost all European languages, predicts the 10-year risk of T2DM-including asymptomatic DM and IGT-with $85 \%$ accuracy. It has been validated in most European populations. [32, 33]

It is necessary to separate individuals into three different scenarios:

(i) the general population;

(ii) people with assumed abnormalities (e.g. obese, hypertensive, or with a family history of DM) and

(iii) patients with prevalent CVD. In the general population and people with assumed abnormalities, the appropriate screening strategy is to start with a DM risk score and to investigate individuals with a high value with an OGTT or a combination of $\mathrm{HbAlc}$ and FPG. [32,33]

In CVD patients, no diabetes risk score is needed but an OGTT is indicated if HbAlc and/or FPG are inconclusive, since people belonging to these groups may often have DM revealed only by an elevated $2 \mathrm{hPG}$.[34-37]

In many countries of the world (E.U., U.S.A., ASIA) high prevalence of major risk factors like smoking, bad 
dietary habits, lack of exercise, alcohol, obesity, arterial hypertension was reported. Recent studies proved that in the U.S.A. and Canada the level of knowledge of health risk factors was very good, but, there was an insufficient knowledge about healthy diet. Those studies showed that both the high level of education and income were protective against the prevalence of health risk factors, morbidity and mortality from all causes, compared to the people with lower income and education.[49-51] Studies in Greece proved that a lot of Greeks don't follow the Mediterranean type of diet $(54.7 \%)$ and there was a relatively lower level of knowledge of the cardiovascular risk factors for those with a lower education level and those residing in Attica-Athens who were following in a lower percentage the healthier Mediterranean style of diet. [47, 48]

Our study revealed that despite the low level of education of many participants ( elementary school graduates) in a percentage more than $>90 \%$ they were aware of the cardiovascular impact of high blood cholesterol, glucose, arterial hypertension but over $60 \%$ underestimated their exact mortality impact on cardiovascular events.

Nevertheless a lot (even those with higher level of education) ignore that low levels of HDL cholesterol are hazardous for cardiovascular health. In general, they knew the impact of bad diet, smoking, obesity, anxiety, and lack of exercise on cardiovascular events regardless of age, sex and educational level. But the specification of the questions revealed lack of knowledge especially for the correlation of smoking and cardiovascular events (even between higher education persons in a lesser degree). Positive correlation was also found among age, marital status, number of kids, educational years, profession, employment and their attitude/ perceptions about prevention.

\section{Conclusions}

Face-to-face interactions between patients and doctors have been identified as the $<<$ heart of medicine $>>$ [41] Also, legislation has been enacted in some US States requiring hospitals and health service providers to have patient and family advisory councils [42].

In line with the aforementioned, organizational health literacy has gained importance in WHO documents and elsewhere in order to facilitate patient-doctor engagement, especially as it pertains to patient information and communications [39],[43,44].

Hospitals and health services should recognize and promote the essential role and centrality of patients, families and citizens in driving the improvement of quality and outcomes of healthcare systems[38].

Although public awareness and health risk factors knowledge is growing, there are gaps in the field of person oriented methodology approach for enhanced health literacy. We need the development of targeted intervention programmes which address the general population in order to change the culture of hospital. This study is the first in our municipality to explore extensively the level of cardiovascular risk factors knowledge, attitude/perceptions on prevention and their association with demographic socioeconomic data towards a health-literated approach.

In our area this pilot study, showed that the burden of the problem for future development of T2D is probably high and there is the need to think globally but act locally towards interdisciplinary working, transparent decision-making and active health-literated involvement of patients.

We know that change happens because people push to make it happen. We've got to do the hard work of educating others, showing empathy to them, changing hearts and minds. And when we do that, then change occurs. It doesn't come always as quickly as we would like, but, eventually progress comes, despite the socio-economy setbacks.

\section{REFERENCES}

[1] International Diabetes Federation 2011. Global Burden: Prevalence and Projections, 2011 and 2030. Online available from

http://www.diabetesatlas.org/content/diabetes-and-impaired-g lucose-tolerance

[2] World Health Organization (WHO) Consultation. Definition and diagnosis of diabetes and intermediate hyperglycaemia. 2006 Online available from http:/www.who.int/diabetes/ publications/Definition\%20and\%20diagnosis\%20of\%20diabe tes_new.pdf

[3] Diagnosis and classification of diabetes mellitus. Diabetes Care 2012; 35 Suppl 1: S64-71.

[4] World Health Organization (WHO), Abbreviated report of a WHO consultation. Use of glycated hemoglobin (HbAlc) in the diagnosis of diabetes mellitus.2011Online available from http://www.who.int/diabetes/publications/diagnosis_diabetes 2011/en/index.html

[5] Diagnosis and classification of diabetes mellitus. Diabetes Care 2010; 33 Suppl 1: S62-69.

[6] CostaB,BarrioF,CabreJJ,PinolJL,CosFX,SoleC,BolibarB,Cast ellC,LindstromJ, Barengo N, Tuomilehto J. Shifting from glucose diagnostic criteria to the new $\mathrm{HbA}(1 \mathrm{c})$ criteria would have a profound impact on prevalence of diabetes among a high-risk Spanish population. Diabet Med 2011;28:12341237.

[7] Pajunen P, Peltonen M, Eriksson JG, Ilanne-Parikka P, Aunola S, Keinanen-Kiukaanniemi S, Uusitupa M, Tuomilehto J, Lindstrom J. HbA (1c) indiagnosing and predicting Type 2 diabetes in impaired glucose tolerance: the Finnish Diabetes Prevention Study. Diabet Med 2011; 28: 36-42.

[8] Gottsater A, Landin-Olsson M, Fernlund P, Lernmark A, Sundkvist G. Beta-cell function in relation to islet cell antibodies during the first $3 y$ rafter clinical diagnosis of diabetes in type II diabetic patients. Diabetes Care1993; 16: 902-910. 
[9] Tuomilehto J, Zimmet P, Mackay IR, Koskela P, Vidgren G, Toivanen L, Tuomilehto-Wolf E, Kohtamaki K, Stengard J, Rowley MJ. Antibodies to glutamic acid decarboxylase as predictors of insulin-dependent diabetes mellitus before clinical onset of disease. Lancet 1994; 343: 1383-1385. 10. Incidence and trends of childhood Type 1 diabetes worldwide 1990-1999.Diabet Med 2006; 23: 857-866.

[10] Kahn SE. The relative contributions of insulin resistance and beta-cell dysfunction to the pathophysiology of Type2 diabetes. Diabetologia 2003; 46: 3-19.

[11] Mari A, Tura A, Natali A, Laville M, Laakso M, Gabriel R, Beck-Nielsen H, Ferrannini E. Impaired betacell glucose sensitivity rather than inadequate compensation for insulin resistance is the dominant defect in glucose intolerance. Diabetologia 2010; 53: 749-756.

[12] Bellamy L, Casas J P, Hingorani A D, Williams D. Type 2 diabetes mellitus after gestational diabetes: a systematic review and meta-analysis. Lancet 2009; 373: 1773-1779.

[13] Feig DS, Zinman B, Wang X, Hux J E. Risk of development of diabetes mellitus after diagnosis of gestational diabetes. CMAJ: Canadian Medical Association journal Journal de l'Association Medicale Canadienne 2008; 179: 229-234.

[14] Carstensen B, Lindstrom J, Sundvall J, Borch-Johnsen K, Tuomilehto J. Measurement of blood glucose: comparison between different types of specimens. Ann Clin Biochem 2008; 45(Pt 2):140-148.

[15] Age-and sex-specific prevalences of diabetes and impaired glucose regulation in13 European cohorts. Diabetes Care2003; 26: 61-69.

[16] Christensen DL, Witte DR, Kaduka L, Jorgensen ME, Borch-Johnsen K, Mohan V, Shaw JE, Tabak AG, Vistisen D. Moving to an AlC-based diagnosis of diabetes has a different impact on prevalence in different ethnic groups. Diabetes Care 2010; 33: 580-582.

[17] Colagiuri S, Lee CM, Wong TY, Balkau B, Shaw JE, Borch-Johnsen K. Glycemic thresholds for diabetes-specific retinopathy: implications for diagnostic criteria for diabetes. Diabetes Care 2011; 34: 145-150.

[18] Pani LN, Korenda L, Meigs JB, Driver C, Chamany S, Fox CS, Sullivan L, D'Agostino RB, Nathan DM. Effect of aging on A1C levels in individuals without diabetes: evidence from the Framingham Offspring Study and the National Health and Nutrition Examination Survey 2001-2004. Diabetes Care2008; 31: 1991-1996.

[19] Saaristo TE, Barengo NC, Korpi-Hyovalti E, Oksa H, Puolijoki H, Saltevo JT, Vanhala M, Sundvall J, Saarikoski L, Peltonen M, Tuomilehto J. High prevalence of obesity, central obesity and abnormal glucose tolerance in the middle-aged Finnish population. BMC Public Health 2008; 8: 423.

[20] Engelgau MM, Colagiuri S, Ramachandran A, Borch-Johnsen K, Narayan KM. Prevention of type 2 diabetes: issues and strategies for identifying persons for interventions. Diabetes Technol Ther 2004; 6: 874-882.

[21] Griffin SJ, Borch-Johnsen K, Davies MJ, Khunti K, Rutten GE, Sandbaek A, Sharp SJ, Simmons RK, van den Donk M, Wareham NJ, Lauritzen T. Effect of early intensive multifactorial therapy on 5-year cardiovascular outcomes in individuals with type 2 diabetes detected by screening
(ADDITION-Europe): a cluster-randomised trial. Lancet 2011; 378: 156-167.

[22] Tuomilehto J, Lindstrom J, Eriksson JG, Valle TT, Hamalainen H, Ilanne-Parikka P, Keinanen-Kiukaanniemi S, Laakso M, Louheranta A, Rastas M, Salminen V, Uusitupa M. Prevention of type 2 diabetes mellitus by changes in lifestyle among subjects with impaired glucose tolerance. N Engl J Med 2001; 344: 1343-1350.

[23] Knowler WC, Barrett-Connor E, Fowler SE, Hamman RF, Lachin JM, Walker EA, Nathan DM. Reduction in the incidence of type 2 diabetes with lifestyle intervention or metformin. N Engl J Med 2002; 346: 393-403.

[24] Roumen C, Corpeleijn E, Feskens EJ, Mensink M, Saris WH, Blaak EE. Impact of 3-year lifestyle intervention on postprandial glucose metabolism: the SLIM study. Diabet Med 2008; 25: 597-605.

[25] Penn L, White M, Oldroyd J, Walker M, Alberti KG, Mathers JC.Preventionoftype 2 diabetes in adults with impaired glucose tolerance: the European Diabetes Prevention RCT in Newcastle upon Tyne, UK. BMC Public Health 2009; 9: 342.

[26] Gillies CL, Abrams KR, Lambert PC, Cooper NJ, Sutton AJ, Hsu RT, Khunti K. Pharmacological and lifestyle interventions to prevent or delay type 2 diabetes in people with impaired glucose tolerance: systematic review and meta-analysis. BMJ 2007; 334: 299-308.

[27] Hare MJ, Shaw JE, Zimmet PZ. Current controversies in the use of haemoglobin A(1c). J Intern Med 2011.

[28] Lerchbaum E, Schwetz V, Giuliani A, Obermayer-Pietsch B. Assessment of glucose metabolism in polycystic ovary syndrome: HbAlc or fasting glucose compared with the oral glucose tolerance test as a screening method. Human Reproduction 2013.

[29] Zhou X, Pang Z, Gao W, Wang S, Zhang L, Ning F, Qiao Q. Performance of an A1C and fasting capillary blood glucose test for screening newly diagnosed diabetes and pre-diabetes defined by an oral glucose tolerance test in Qingdao, China. Diabetes Care 2010; 33: 545-550.

[30] Abbasi A, Peelen LM, Corpeleijn E, vander Schouw YT, Stolk RP, Spijkerman AM, vander AD, Moons KG, Navis G, Bakker SJ, Beulens JW. Prediction models for risk of developing type 2 diabetes: systematic literature search and independent external validation study. BMJ 2012; 345: e5900.

[31] Lindstrom J, Tuomilehto J. The diabetes risk score: a practical tool to predict type2 diabetes risk. Diabetes Care 2003; 26 : 725-731.

[32] Schwarz PE, Li J, LindstromJ, Tuomilehto J. Tools for predicting the risk of type 2 diabetesin daily practice. Horm Metab Res2009;41:86-97.

[33] Bartnik M, Ryden L, Malmberg K, Ohrvik J, Pyorala K, Stand 1E, Ferrari R, Simoons M, Soler-Soler J. Oral glucose tolerance test is needed for appropriate classification of glucose regulation in patients with coronary artery disease: a report from the Euro Heart Survey on Diabetes and the Heart. Heart 2007; 93: 72-77.

[34] Hage C, Lundman P, Ryden L, Mellbin L. Fasting glucose, $\mathrm{HbA} 1 \mathrm{c}$,or oral glucose tolerance testing for the detection of glucose abnormalities in patients with acute coronary 
syndromes. Eur J Prev Cardiol 2012.

[35] de Mulder M, Oemrawsingh RM, Stam F, Boersma E, Umans VA. Comparison of diagnostic criteria to detect undiagnosed diabetes in hyperglycaemic patients with acute coronary syndrome. Heart 2012; 98: 37-41.

[36] Doerr R, Hoffmann U, Otter W, Heinemann L, Hunger-Battefeld W, Kulzer B, Klinge A, Lodwig V, Amann-Zalan I, Sturm D, Tschoepe D, Spitzer SG, Stumpf J, Lohmann T, Schnell O. Oral glucose tolerance test and $\mathrm{HbA}(1) \mathrm{c}$ for diagnosis of diabetes in patients undergoing coronary angiography:[corrected]the Silent Diabetes Study. Diabetologia 2011;54:2923-2930.

[37] Berwick DM (2009). What 'patient-centered' should mean: confessions of an extremist. Health Affairs, 28(4):w555w565.

[38] Brach C, Keller D, Hernandez LM, Baur C, Parker R, Dreyer B, Schyve P, Lemerise AJ, Schillinger D (2012). Ten Attributes of Health Literate Health Care Organizations. National Academy of Science. Online available from: http://www.ahealthyunderstanding.org/Portals/0/Documents1 /IOM_Ten_Attributes_HL_Paper.pdf

[39] Conklin A, Morris ZS, Nolte E (2010). Involving the public in healthcare policy: An update of the research evidence and proposed evaluation framework. Bertelsman Foundation. Santa Monica, CA: RAND Corporation.

[40] Epstein RM, Campbell TL, Cohen-Cole SA, Mc Whinney IR, Smilkstein G (1993). Perspectives on patient-doctor communication. The Journal of Family Practice, 37:377-388.

[41] Massachusetts Commonwealth 189th Court (2009). Section $53 \mathrm{E}$ on the creation of Patient and Family Advisory Councils. Online available from:

https://malegislature.gov/Laws/GeneralLaws/PartI/TitleXVI/ Chapter111/Section53e.
[42] World Health Organization (2009). Nairobi Call to Action. Geneva: World Health Organization.

[43] World Health Organization (2013). Health Literacy. The solid facts. Copenhagen: World Health Organization Regional Office for Europe.

[44] Risk models and scores for type 2 diabetes: systematic review Douglas Noble, Rohini Mathur, Tom Dent, Catherine Meads, Trisha Greenhalg BMJ. 2011 Nov 28;343:d7163. doi: 10.1136/bmj.d7163 (Published 28 November 2011).

[45] The validity of the Finnish Diabetes Risk Score for the prediction of the incidence of coronary heart disease and stroke, and total mortality Karri Silventoinen, James Pankow, Jaana Lindström, Pekka Jousilahti, Gang Hu, Jaakko Tuomilehto. Online available from: http://journals.sagepub.com/doi/abs/10.1097/01.hjr.00001747 93.31812 .21

[46] Online Available: http://estia.hua.gr:8080/dspace/bitstream/123456789/1509/1/ patsali_elsa.pdf

[47] Online Available: http://www.mednet.gr/archives/2010-5/pdf/793.pdf

[48] Feldman JJ, Makuc DM, Kleinman JC, Cornoni-Huntley J.National trends in educational differentials in mortality. Am J Epidemiology. 1989; 129: 919-933.

[49] Kirkland SA, McLEAN DR, LANGILLE DB, JOFFRES MR, McPHERSON KM, ANDREOU P. Knowledge and awareness of risk factors for cardiovascular disease among Canadians 55 to 74 years of age: Results from the Canadian Heart Health Surveys, 1986-1992. CMAJ 1999, 161(Suppl 8):S10-S16

[50] Kitagawa EM \& Hauser PM (1973). Differential Mortality in the United States: A study in socioeconomic epidemiology. Cambridge, MA: Harvard University Press. 